\title{
CEPHALIC GLANDS IN GELASTOCORIS
}

\author{
(HEMIPTERA-HETEROPTERA)
}

\author{
By Margaret C. Parsons ${ }^{1}$
}

\section{Biological Laboratories, Harvard University}

In the literature on the anatomy of the aquatic Cryptocerata (Hemiptera-Heteroptera) there are many references to the "cephalic" or "maxillary" glands. These large cylindrical or sac-like structures, whose external openings lie at the base of the labium, are located on either side of the head in the Corixidae (Banks, 1939; Benwitz, 1956), Notonectidae (Bordas, 1905 a; Bugnion and Popoff, 1908), Naucoridae (Becker, 1929; Rawat, 1939), and Belostomatidae (Locy, 1884; Bugnion and Popoff, 1908). In the Nepidae, they may be partly (Nepa; Bordas, $1905 \mathrm{~b}$ ) or entirelv (Ranatra; Bugnion and Popoff. 1908; Neiswander, 1925) contained in the thorax, with ducts leading to the openings in the head. Previous investigations of these glands in the Cryptocerata have mentioned their presence only in the aquatic forms; they have never been reported in the shore-dwelling cryptocerates.

While studying the anatomy of the shore-dwelling cryptocerate Gelastocoris oculatus oculatus ( Fabricius) (Gelastocoridae), the author noted two large, sac-like structures, one lying on either side of the ventral part of the head. Figure 1 indicates, in dotted lines, their approximate position, which is revealed by cutting away the exoskeleton from the entire ventral surface of the head. They lie immediaetly beneath this exoskeleton, extending anteriorly to the base of the labium and posteriorly a little beyond the antennal socket. Anteriorly they reach nearly to the

1 This research was carried out during the tenure of the Ellen C. Sabin Fellowship, awarded by the American Association of University Women. Thanks are due to the members of the C. V. Riley Entomological Society, Columbia, Missouri, who collected the specimens of Gelastocoris. 
midline, but diverge from each other posteriorly in the region of the subesophageal ganglion. They are bordered dorsally by the mandibular lever and the retractor muscles of the mandibular and maxillary stylets, and laterally by the sides of the head. The fact that these structures contain copious amounts of a milky secretion, and that their lumina open through definite orifices, suggests that they are glandular in nature. When the bug is disturbed, large quantities of this secretion are emitted from the large orifices, which are located on the ventral surface of the head just anterior to the antennal sockets (Fig. 1). In the following discussion, the term "orifice" will refer only to the hole in the exoskeleton, while the mouth of the gland, lying beneath the orifice, will be termed the "glandular opening."

The opening mechanism of the gland is controlled by a slender muscle, which originates on the tip of the posterior wing of the hypopharynx and runs ventral to the gland to insert on a flap on the medial side of the glandular opening (Fig. 4). This flap is sclerotized and elastic; its two

EXPLANation or I'LITE 12

Figures 1-3. Ventral views of the heads of representative Cryptocerata, showing the positions of the orifices of the cephalic glands. The eyes are colored solid black. Figure 1. Gelastocoris oculatus oculatus. The dotted lines indicate the approximate position of the cephalic glands inside the head. $20 \mathrm{X}$. Figure 2. Notonecta undulata. $10 \mathrm{X}$. Figure 3. Belostoma flumineum. The labrum and labium have been cut off at the base of the second labial segment. $13 \mathrm{X}$. Figures 4 and 5 . Views of the inner ventral surface of the head of Gelastocoris, showing the opening mechanism of the left cephalic gland. The anterior direction is to the top, the posterior direction to the bottom, the lateral direction to the left, and the medial direction to the right of the diagram. $375 \mathrm{X}$. Figure 4. The muscle is relaxed, and the glandular opening is shut off from the orifice in the exoskeleton. Figure 5. The muscle is contracted, and the glandular opening is pulled over beneath the orifice.

Abreviations Used in Plate: A - antenna; F - sclerotized flap on medial side of glandular opening; $\mathrm{G}$ - gula; L - labium; LG - lateral wall of glandular opening; LB - labrum; $M$ - muscle inserting on sclerotized flap; MG - medial wall of glandular opening; MP - maxillary plate; $\mathrm{O}$ - orifice in exoskeleton of head; OF - occipital foramen. 


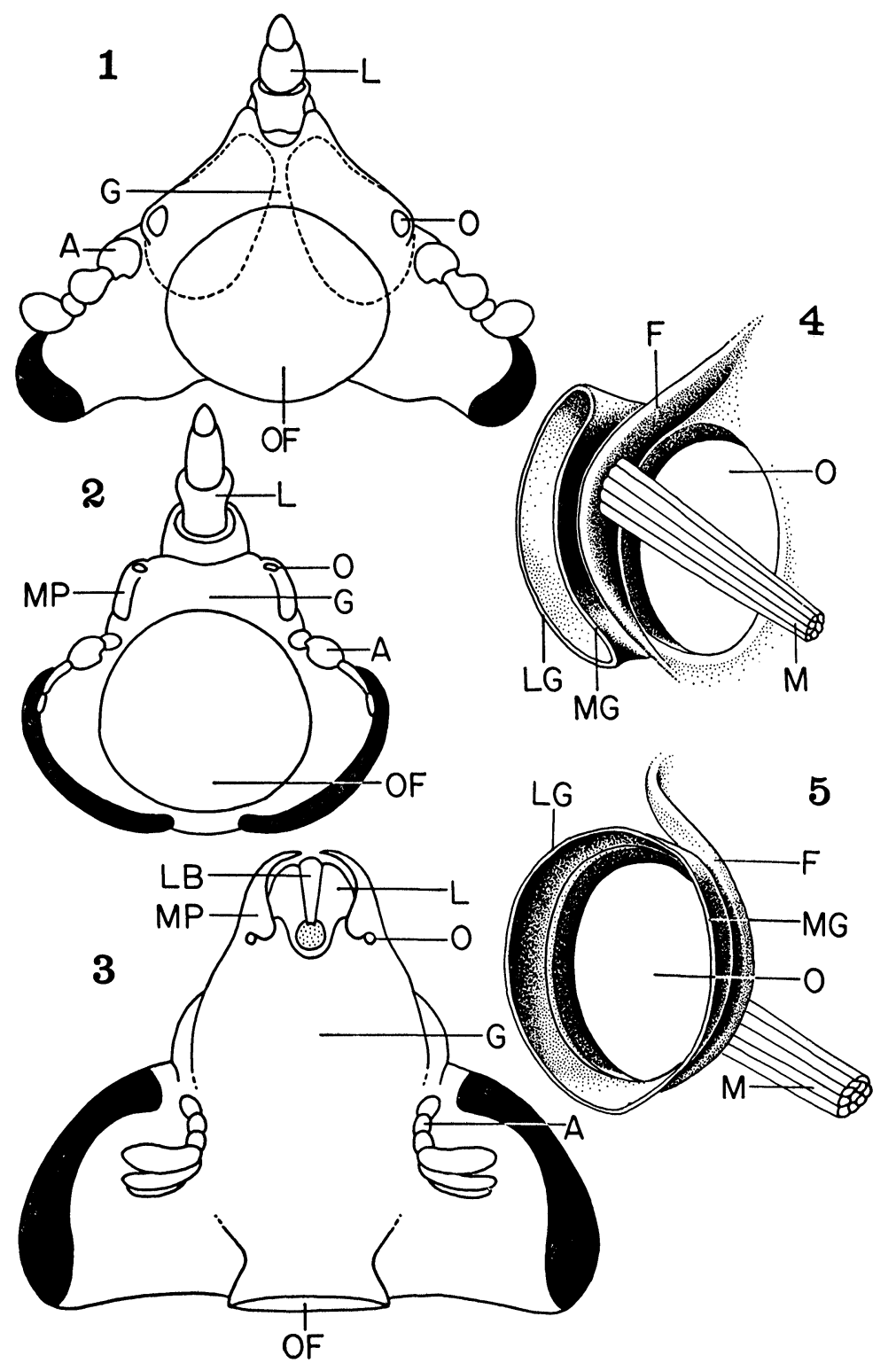

Parsons - Cryptocerata 
ends are fused to the exoskeleton of the head on either side of the orifice, while its middle part is connected to the medial side of the glandular opening. When the muscle is relaxed, the flap lies just beneath the lateral edge of the orifice, and thus separates the orifice, which lies medial to it, from the glandular opening, which is lateral to it (Fig. $4)$. When the muscle contracts, the flap is pulled over to just beneath the medial side of the orifice; the glandular opening then lies immediately below the orifice, and the secretion can escape through the latter (Fig. 5).

The wall of the gland is very smooth and delicate, and appears silvery in freshly dissected specimens. Its histology was examined in serial sections through the heads of two fifth-instar nymphs and three adults of Gelastocoris; the material was fixed in Carnoy's or alcoholic Bouin's, prepared for sectioning by means of the Peterfi method, and stained in either Mallory's triple connective-tissue stain or in Delafield's hematoxylin and eosin. Text-figure 1 shows the general appearance of the glandular epithelium in an adult specimen. It is comprised of a simple layer of cells with no suggestion of an acinar arrangement. The most conspicuous elements are the large cells, which are usually flat in adult gelastocorids but appear more cubiodal or cylindrical in the nymphs. These cells probably produce the secretion. Their large nuclei are about $15 \mu$ in diameter, and contain conspicuous nucleoli and many chromatin granules of various sizes. The cytoplasm is homogeneous and deeply staining in adults but appears more vacuolar in nymphs. An intracellular canaliculus with striated walls penetrates the cytoplasm of each large cell; it seems to run across the cell in an obliquely transverse direction, opening onto the lumen of the gland usually near the lateral boundary of the cell.

The lumen of the gland is lined by a delicate chitinous intima, which does not appear to penetrate into the canaliculi. Lying along the intima or between the intima and the large cells are small spindle-shaped nuclei, whose cytoplasm is either very sparse or absent; their greatest diameter ranges between 5 and $10 \mu$. In many parts of the epithelium the large cells are absent, and only the in- 
tima and the small nuclei remain. Such regions are not confined to any definite area of the gland, and their location varies from one individual to the next. The epithelium is never more than 15 or $20 \mu$ thick, and the bulk of the gland consists merely of the very extensive lumen filled with a homogeneous, finely granular secretion which stains blue in Mallory's triple connective-tissue stain and pink in Delafield's hematoxylin and eosin.

These glands in the Gelastocoridae resemble in several ways the cephalic glands of aquatic Cryptocerata, and the similarities suggest that the former are homologous with the latter. Their paired ventral position in the head corresponds to that described by other authors for the cephalic glands of the Notonectidae, Naucoridae, Belostomatidae, and Corixidae (in the last family only the anterior part of the gland is ventral, the posterior part being dorsal to the brain). The simple sac-like shape of the gelastocorid glands is consistent with the previous descriptions of cephalic glands in aquatic bugs; to the author's knowledge, only the Naucoridae show a more complicated structure, having a lobed reservoir beside the glandular part of each gland (Becker, 1929; Rawat, 1939). A muscle controlling the opening mechanism of the gland has been described in Corixa and Notonecta (Benwitz, 1956) and in Naucoris (Becker, 1929) ; although in the former two genera this muscle originates on the wall of the head, in Naucoris it is attached, like that of Gelastocoris, to the tip of the posterior wing of the hypopharynx.

Histologically there are further resemblances. The three main components, the large cells, the smaller cells, and the chitinous intima, are mentioned in Corixa (Benwitz, 1956), Naucoris (Rawat, 1939), Ranatra (Bugnion and Popoff, 1908), and Notonecta (Bordas, 1905 a). The secretory epithelium is reported to be arranged into acini in Naucoris (Becker, 1929; Rawat, 1939) and Notonecta (Bugnion and Popoff, 1908), but no such arrangement is mentioned for the other forms. Locy (1884), Bugnion and Popoff (1908), and Benwitz (1956) report intracellular canaliculi within the large cells, similar to those seen in 
Gelastocoris, and the last author describes the striations along these canaliculi.

The main difference between the glands of Gelastocoris and those of the aquatic Hemiptera is in the position of their external openings. Whereas in the aquatic Cryptocerata the orifices lie at or near the base of the labium, in Gelastocoris they are located much farther posteriorly on the head. A comparison of Figure 1 with Figures 2 and 3 points out this difference; Notonecta undulata and Belostoma flumineum are used as representatives of the aquatic forms.

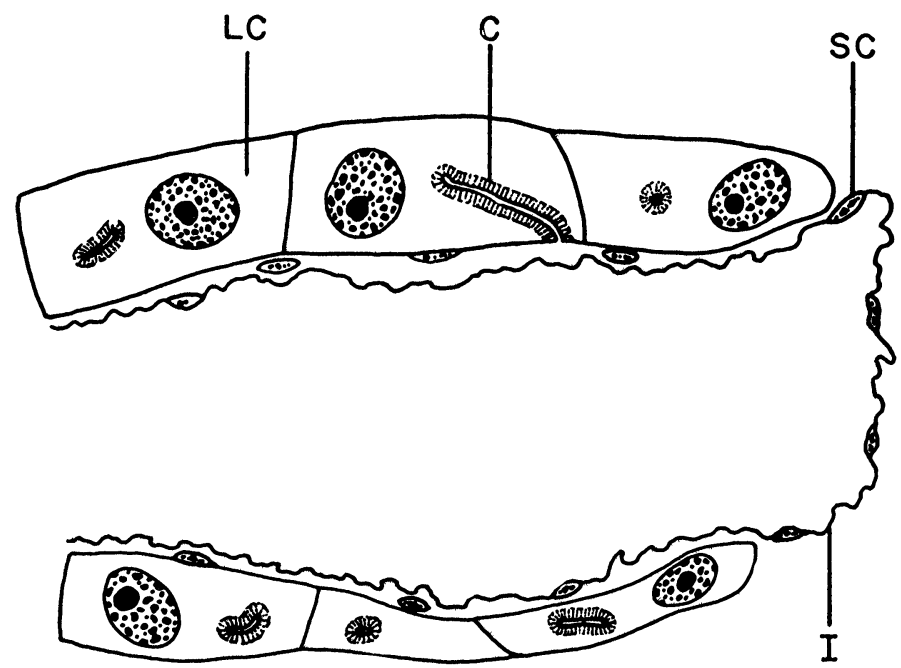

Text-figure 1. Diagrammatic transverse or longitudinal section through the epithelium of the cephalic gland in an adult Gelastocoris. In this diagram the epithelium is folded double, so that the lumen appears much narrower than it actually is. The canaliculus of the upper middle large cell is shown opening onto the lumen of the gland; the other canaliculi are diagrammed in transverse or oblique section. $700 \mathrm{X}$.

Abbreviations used in figure: $\mathrm{C}$ - canaliculus; I - intima; LC large cell; SC - small cell.

The function of the cephalic glands in the water bugs has not yet been satisfactorily established. Previous workers have suggested (1) that their secretion is used in sub- 
duing prey, being somehow injected into or ingested by their victims, (2) that the secretion is defensive, serving to repel predators, or (3) that the glands function as excretory organs. The last theory was proposed by Becker (1929), but it was attacked by Rawat (1939) who found that carmine injected into the head of Naucoris was not taken up by the glands; the first two theories appear to be the most popular. In Gelastocoris it is unlikely that the secretion of the cephalic glands could be used for killing or paralyzing prey, since the orifice is a good distance from the beak. It seems most probable that it has a defensive function.

To the author's knowledge, cephalic glands have been reported in only three Gymnocerata. Macgill (1947) gave a brief description of two groups of glandular cells in the phytophagous bug Dysdercus (Pyrrhocoridae). These cells lie near the stylets and open onto the anterior part of the maxillary plate, at the base of the labium, by many small pores. Macgill considered their function to be the lubrication of the stylets; no histological details were given. Bugnion and Popoff (1911) figured maxillary glands in a section through the head of Pyrrhocoris (Pyrrhocoridae), but gave no histological description and did not mention the position of the external orifice. A brief account of maxillary glands in Oncopeltus (Lygaeidae) was given by Linder and Anderson (1955). It seems therefore that the cephalic glands are characteristic of the Cryptocerata but occur in the Gymnocerata. According to China (1955), the shore-dwelling families Gelastocoridae and Ochteridae are the most primitive of the Cryptocerata, having diverged from the ancestral line before it became aquatic. To date, however, the relationships between the aquatic and shore-dwelling Cryptocerata have been hypothesized mainly on the basis of external structural characters. The presence of cryptocerate-like cephalic glands in Gelastocoris offers some evidence from internal morphology that the Gelastocoridae are closely related to the aquatic Cryptocerata.

It might be proposed, on the basis of China's evolutionary theory, that the position of the orifice in Gelastocoris is the primitive condition, while that seen in the aquatic bugs is 
a specialization, possibly accompanying a partial or total shift in glandular function from a defensive organ to a poison gland. Since, in all the aquatic bugs studied, the orifice is always near the base of the beak, bordering on the maxillary plate (Benwitz, 1956), any change to this location from that seen in Gelastocoris would have to have occurred just before the primitive line diverged into separate aquatic families. Against this theory, however, is Macgill's observation that the opening of the glands in the gymnocerate Dysdercus are at the base of the labium. This suggests that this location of the orifice is the primitive condition, and was found in the Proto-Heteroptera (to use the term of China, 1955) before the Gymnocerata and Cryptocerata diverged. If this theory is correct, the more posterior position of the orifice in Gelastocoris is a secondary acquisition. Why such a shift should take place is not clear, however, since the gelastocorids are predators, like their aquatic relatives, and orifices associated with the labium, which could allow the glands to serve as poison glands, would be advantageous to them. Although the second of these theories appears at this time to be the more commendable, more information on the presence or absence of cephalic glands in other Heteroptera, and on the location of their orifices, is needed to shed further light on this problem.

BANKs, C. J.

Literature Cited

1939. Cephalic glands in the Corixidae. Proc. R. Ent. Soc. Lond. (Ser. A), $14: 83-85$.

BeCKer, E.

1929. Zum Bau des Kopfes der Rhynchoten. I Teil. Bau des Kopfes von Naucoris cimicoides L. Rev. Zool. Russe, 9:1-53 (in Russian) and 54-96 (in German).

Benwitz, G.

1956. Der Kopf von Corixa punctata Ill. (geoffroyi Leach) (Hemiptera-Heteroptera). Zool. Jahrb. (Abt. Anat.), 75:311-378.

Bordas, M. L.

1905 a. Sur les glandes salivaire céphaliques et métathoracique des quelques Hémiptères. C. R. Acad. Sc1. Paris, 140:595-597.

1905 b. Les glandes salivaires des Nepidae (Nepa cinerea L.). Anat. Anz., 26:401-406. 
Bugnion, E. and N. Popoff.

1908. L'appareil salivaire des Hémiptères. Arch. d'Anat. Micr., 10:227-268.

1911. Les pièces buccales des Hémiptères. Arch. Zool. Exp., $7: 643-674$.

China, W. E.

1955. The evolution of the water bugs. Bull. Nat. Inst. Sci. India, y: $91-103$.

Linder, F. J. and J. M. Anderson.

195E. Structure and histochemistry of the maxillary glands in the milkweed bug, Oncopeltus fasciatus (Hemiptera). Anat. Rec., $122: 489$.

Locy, W. A.

1884. Anatomy and physiology of the family Nepidae. Amer. Nat., 18:250-255 and 353-367.

MACGILL, E. I.

1947. The anatomy of the head and mouth-parts of Dysdercus intermerius Dist. Proc. Zool Soc. Lond., 117:115-128.

NeIswander, C. R.

1925. On the anatomy of the head and thorax in Ranatra (Heteroptera). Trans. Amer. Ent. Soc., 51:311-320.

Rawat, B. L.

1939. Notes on the anatomy of Naucoris cimicoides L. (HemipteraHeteroptera). Zool. Jahrb. (Abt. Anat.), 65:535-600. 

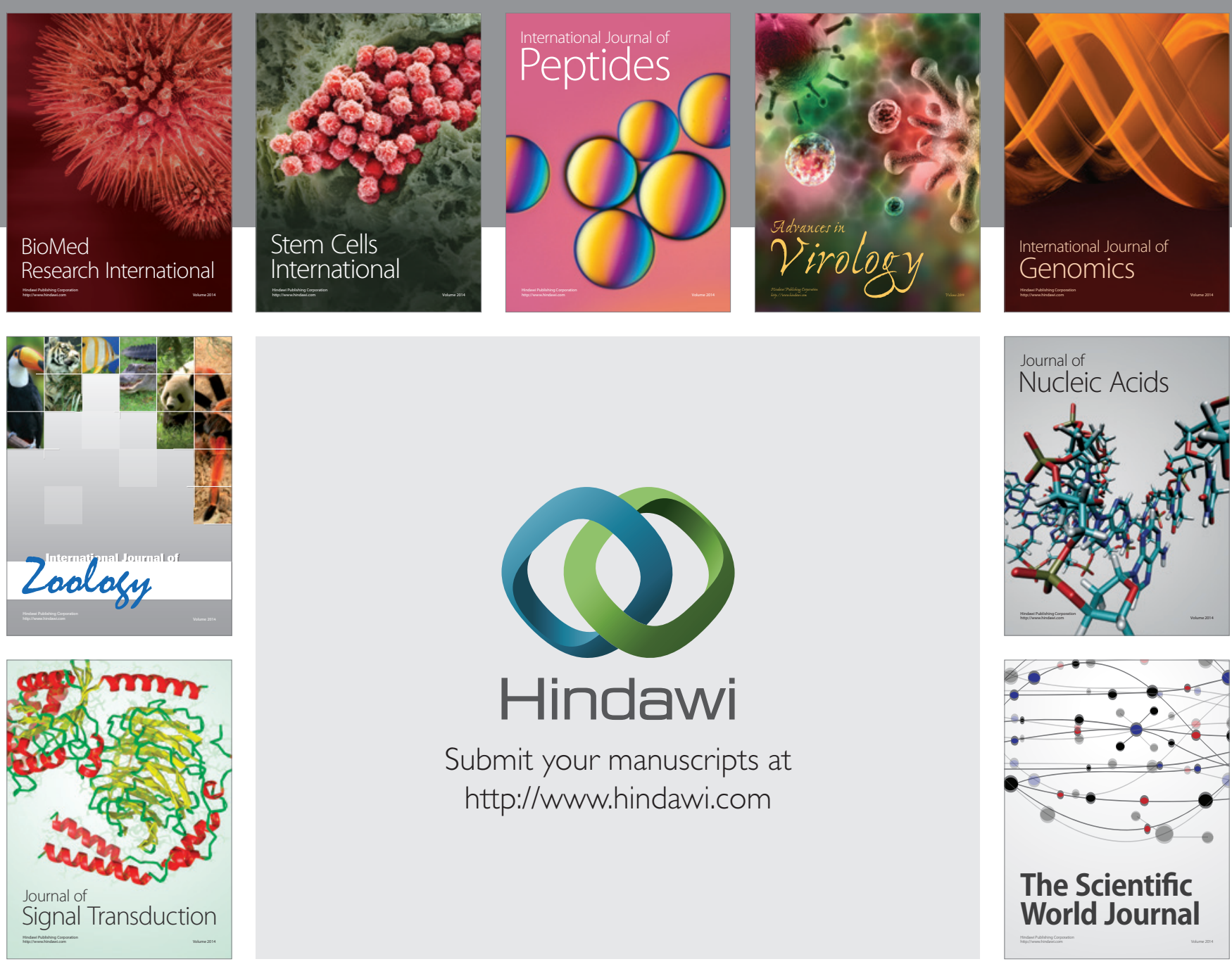

Submit your manuscripts at

http://www.hindawi.com
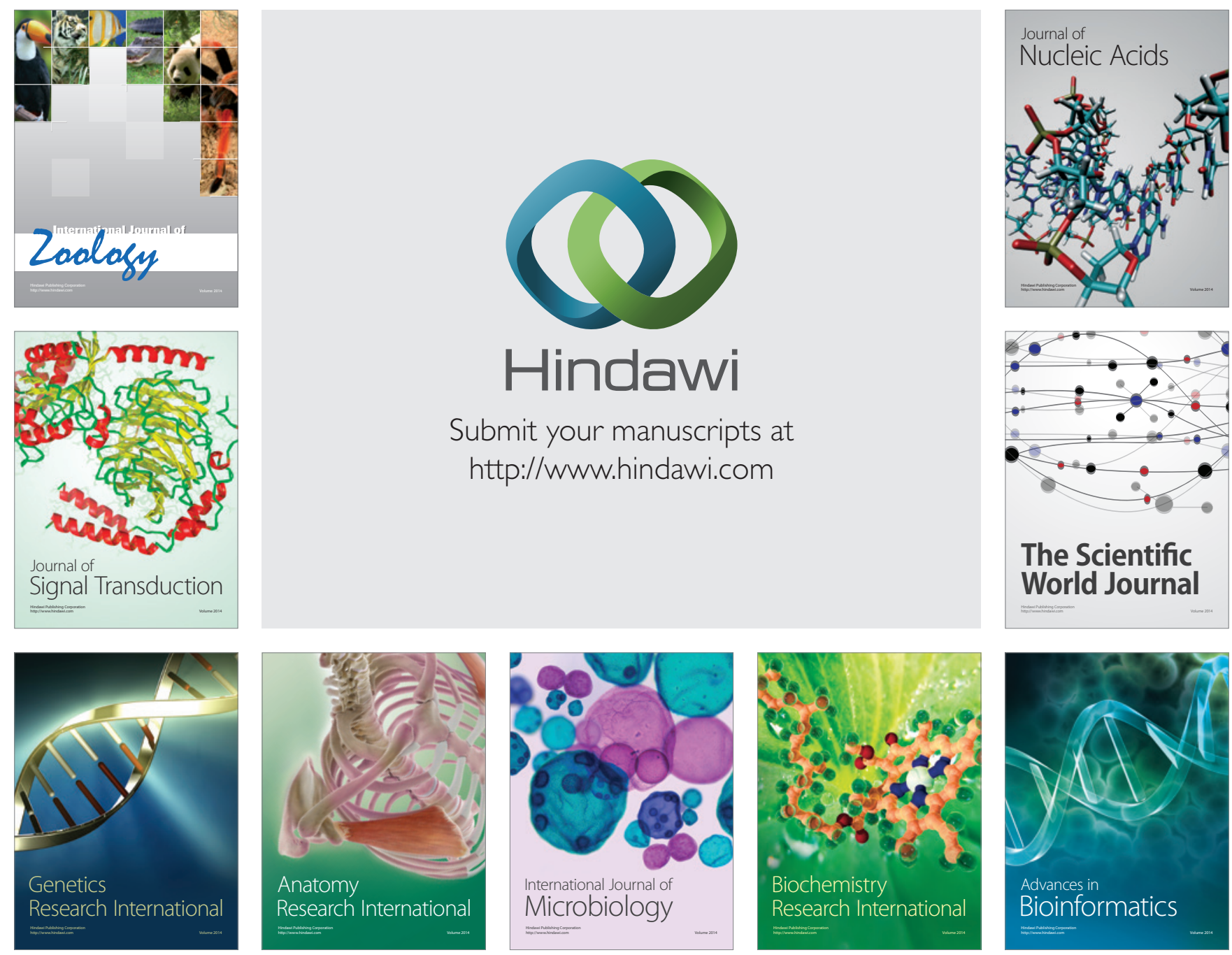

The Scientific World Journal
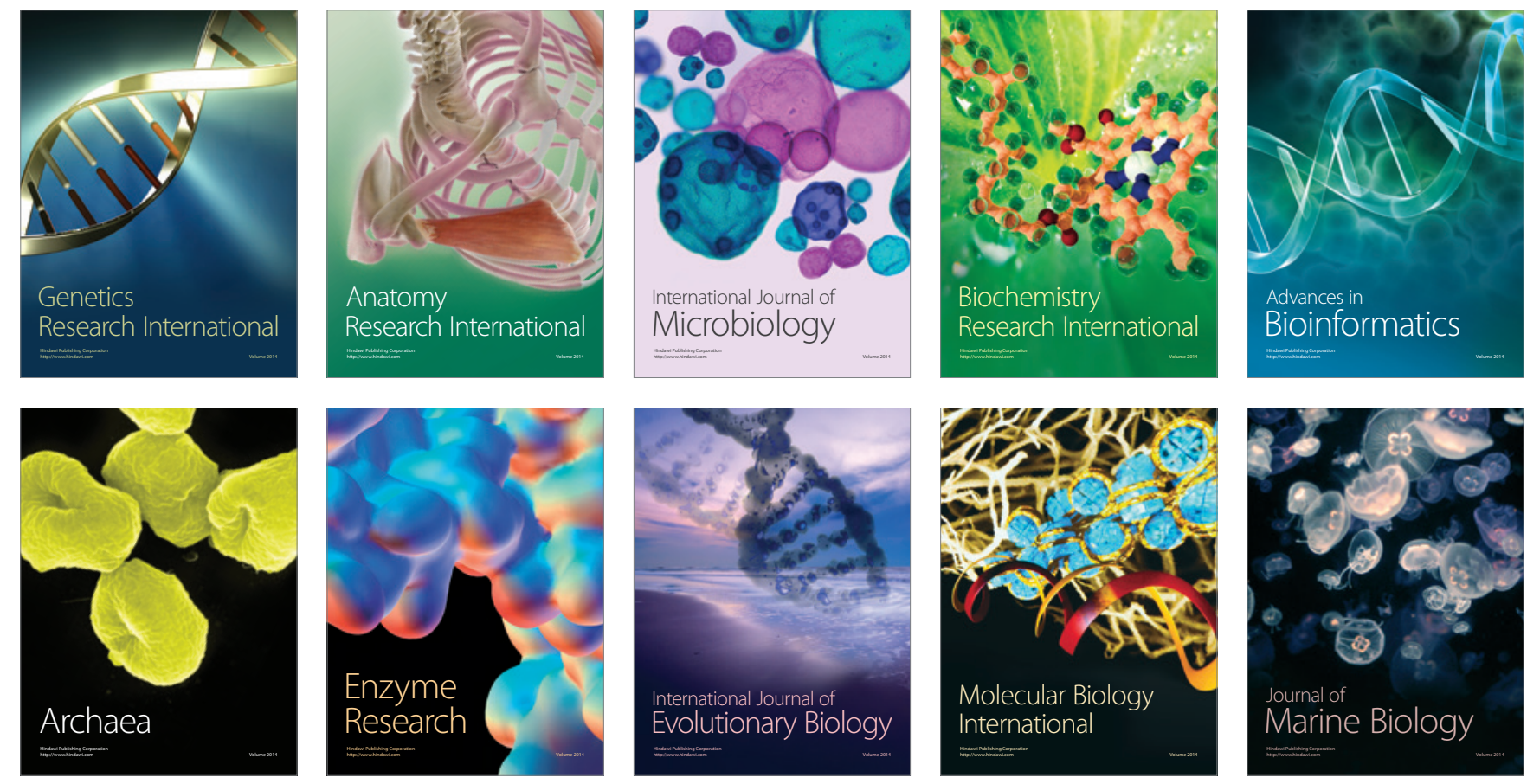